\title{
On the Messianic Expectation of Nichiren: in Comparison to Christology
}

\section{Makoto Ozaki}

According to Christian doctrines, Jesus has no sin, is sinless in principle, whereas even after the attainment of perfection in Buddhahood, the Buddha can intend to humiliate himself and assume the imperfect form or badness in order to save other imperfect beings in a way of assimilating himself to them. This concept of Bodhisattva encompasses two aspects of attained perfection and includes one of imperfection in the present state. This paradoxical duality, or double structure, denotes the possible transition between past and future state of perfection through the present act, for the old Buddha in the past takes the form of new Bodhisattva in the future.

The relationship between Buddha and Bodhisattva has a double direction, namely, "from below" and "from above"; in the case of direction "from below", Bodhisattva strives to attain Buddhahood with personal movement toward the perfect, historical Buddha, and in the case of direction "from above", the Buddha descends down into the sphere of human history for the purpose of saving mankind from the perspective of his original and eternal vision. This occurs concurrently in the vertical dimension of eternity, even though actually taking place in succession on the horizontal plane of history. So, it might be said that Bodhisattva is another name of the Buddha, and vice versa. We must ask, why does this occur? The solution is not so plain apart from referring to the issue of sin. Human beings are unavoidably involved in sin since birth, this is called "original sin" in the Western religion and "the inherited retribution" in the Eastern one. Redemption from inevitable sin requires that Buddha or God comes down into the human involvement; this is the meaning of Christ or Bodhisattva as Saviour. It is also common to both that, after the deaths of Jesus Christ and the Buddha, the second coming of Christ and the reappearance of the Buddha transformed as Bodhisattva are expected for future generations who are still 
unredeemed.

With regard to the retroactive establishment of the mutual identity of Jesus and the Christ from the perspective of the resurrection, the confirmation of Jesus' unity with God does not mean that Jesus had received divinity only as a consequence of his resurrection, but that he was what he is, namely, he was previously one with God. Jesus' original eternal divinity is retroactively confirmed from the perspective of his resurrection, and this historical perspective makes it possible to warrant his historical and earthly humanity as well. If not so, and presupposing his eternal divinity from the start, the historical reality, which is properly appropriate for his humanity, would be lost from our sight, and remain there merely a shadow on the horizon of history. On the other hand, from the perspective of the revelation of the historical Buddha's eternal origin, all other Buddhas who preceded and succeed him turn out to be retroactive self-manifestations of the original, eternal Buddha. In addition, the self-projection of the eternal Buddha into the future closely corresponds to an aspect of the eternal Son of God, who is to incarnate in history. This protological origin is balanced by an eschatological hope in the future, which is pregnant in anticipation of the reappearance of the Buddha.

The importance of the revelation of God in Jesus as the Christ lies in that Jesus is a historical entity, not an image, and the Absolute must be mediated through a relative being, which is no other than a historical figure, for the sake of its own self-realization; in other words, the Absolute cannot exist by itself, but only exists in relation to that which is relative. Without a historical presence, there would be no dynamic unity between eternal essence and human existence, but rather, only pure potentiality.

In the Buddhism of the Lotus Sutra, the Buddha Śakyamuni has the double meaning: the historical and the eternal. Although the eternal Buddha exists prior to his historical manifestation in the depth of his order of being, it is only retroactively recognized from the historical Buddha's own self-awaking of his very deep root origin. After the establishment of the eternal Buddha in origin it is possible for us to establish our own movement toward becoming a Buddha. This is the criterion of becoming a Buddha. Hence, it is parallel to the principle 
of Jesus Christ, who eternally took place prior to his actual event in history. So, Nichiren expounds, "because they teach that Shakyamuni Buddha attained enlightenment for the firsttime in India and do not explain his true identity, they fail to reveal the fact...that the Buddha attained enlightenment countless eons ago". This eternal becoming of the Buddha is regarded as the criterion, according to which every person can attain the Buddhahood, having the affinity with the eternal pre-existence of Jesus Christ.

According to the Lotus Sutra, especially the chapter on the Buddha's Eternal Life, there have been so many self-manifestations of the eternal Buddha until now, the historical Buddha $\hat{S} \bar{a} k y a m u n i$, with different names and various forms. Those different Buddhas in the past and in the other worlds are ultimately to be ascribed to the only One Buddha, who the historical Buddha revealed; namely, all other Buddhas are no other than the branches of the eternal Buddha, and hence they constitute the self-identity in the end. However, they are not always equal in value and purpose, but rather ordered into a serial sequence, constituting the final achievement of salvation. This is the content of the self-manifesting course of the eternal Buddha, who has now at last reached the satisfaction in the immensely long history of redemption from human's sins and evils. So, there is the order of successive appearences of the Buddhas in the course of salvation history, which is beyond our world.

In the light of the climax of the Buddha's self-continuing enlightenment, all past Buddhas are not only fully legitimated into the order of the history of salvation as his own self-manifestation, but also a new course of salvation commences for the future people after his passing, and this is anticipated as the emergence of the Bodhisattva from the abyss of time. This unseen Bodhisattva, as if being inferior to the Buddha in form, nonetheless, stands for the eternal Buddha himself, for the commencement of a new redemptive work is exclusively pertinent to the latter and that form is simply a symbolic reference to the future effect to be disclosed as the last resort. In short, the Buddha has completed the salvation circle at the culmination. So, Nichiren explains, "On the surface the Buddha seems to have preached this teaching for the salvation of people of his day...In actuality, however, preparation, revelation, and transmission of the 
essential teaching are intended entirely for the beginning of the Latter Day of the Law...Shakyamuni's is the Buddhism of the harvest, and this is the Buddhism of sowing". Here it is so apparent that as soon as the Buddha culminates in sheer enlightenment, he also begins the circle of salvation, taking the form of Bodhisattva, who strives after the original enlightenment lost in countless journeys of lives in the far past. As a result, the Buddha's history of salvation coexists with the world-history of human beings.

Compared with Jesus Christ, the number of times of the incarnation of the eternal Buddha is not restricted to only once, but at least twice in this world, that is, the Buddha Sakyamuni and the Bodhisattva, who was predestined to come out in the Lotus Sütra. Then, how is he related to Jesus Christ? With regard to this problem, Nichiren's utterance is highly significant in that "the final conclusion of these non-Buddhist teachings constitutes an important means of entry into Buddhism...All scriptures or teachings, from whatever source, are ultimately the revelation of Buddhist truth. They are not non-Buddhist teachings". This proves that from the perspective of the Buddha's inner full enlightenment, even other religions than Buddhism turn out to play the roles of preparation for the full manifestation of Buddhist truth, though provisional and partial, in latent ways. So, in respect to historical figures, he paradoxically announces, "They (the Buddha's disciples) will display the three poisons and appear to cherish misleading philosophies. This is the means by which my disciples save the people". He also declares, "it is true that all sages and wise men, who were born all over the world, including India, China, and Japan, during a period of more than two thousand two hundred and twenty years after the Buddha's demise, are regarded as the incarnations of the Buddha Säkyamuni...". Thus, in terms of eternity, all those people, who played respective important roles in philosophy and religion in the history of human race, are no less than, to some extent and to a differing degree, embodiments of the eternal and original Buddha as ultimate reality in the final analysis. Any way, Nichiren is understood as the historical actualization of the expected Bodhisattva who was the self-projection of the eternal Buddha. (References are omitted.)

(Research Fellow, Institute of Oriental Philosophy) 